\title{
Active tectonics of the Calabrian subduction revealed by new multi-beam bathymetric data and high-resolution seismic profiles in the Ionian Sea (Central Mediterranean)
}

\author{
Gutscher Marc-André ${ }^{1{ }^{*}}$, Kopp Heidrun ${ }^{2}$, Krastel Sebastian ${ }^{3}$, Bohrmann Gerhard ${ }^{4}$, Garlan Thierry ${ }^{5}$, \\ Zaragosi Sebastien ${ }^{6}$, Klaucke Ingo ${ }^{2}$, Wintersteller Paul ${ }^{4}$, Loubrieu Benoit ${ }^{7}$, Le Faou Yann ${ }^{5}$, \\ San Pedro Laurine ${ }^{1}$, Dominguez Stephane ${ }^{8}$, Rovere Marzia ${ }^{9}$, Mercier De Lepinay Bernard ${ }^{10}$, \\ Ranero Cesar ${ }^{11}$, Sallares Valenti ${ }^{11}$
}

${ }^{1}$ Laboratoire Géosciences Océan, Univ. Brest/CNRS, 29280 Plouzané, France

2 GEOMAR Helmholtz Centre for Ocean Research, 24148 Kiel, Germany

${ }^{3}$ Christian-Albrechts Universität zu Kiel, 24118 Kiel, Germany

${ }^{4}$ MARUM University of Bremen, 28334 Bremen, Germany

${ }^{5}$ Service Hydrographique et Océanographique de la Marine (SHOM), 29228 Brest, France

${ }^{6}$ EPOC-Univ. Bordeaux, 33405 Talence, France

7 Ifremer, Géosciences Marines - EDROME, 29280 Plouzané, France

${ }^{8}$ Geosciences Montpellier, Univ. Montpellier, 34095 Montpellier, France

${ }^{9}$ Institute of Marine Sciences ISMAR/CNR, 40129 Bologna, Italy

${ }^{10}$ GeoAzur, Univ. Nice/CNRS, 06560 Sophia-Antipolis, France

${ }^{11}$ CSIC-CMIMA, 08003, Barcelona, Spain

* Corresponding author : Marc-André Gutscher, email address : gutscher@univ-brest.fr

\begin{abstract}
:
The detailed morphology and internal structure of the Calabrian accretionary wedge and adjacent Eastern Sicily margin are imaged in unprecedented detail by a combined dataset of multi-beam bathymetry and high-resolution seismic profiles. The bathymetric data represent the results of 6 recent marine geophysical surveys since 2010 as well as a compilation of earlier surveys presented as a 2 arcsec $(60 \mathrm{~m})$ grid. Several distinct morpho-tectonic provinces are identified including: the deeply incised Malta-Hyblean Escarpment, numerous submarine canyons, broad regions of relatively flat seafloor dominated by fields of sediment waves, the gently undulating anticlinal fold-and-thrust belts of the external Calabrian accretionary wedge and the adjacent portion of the Western Mediterranean Ridge. The Calabrian arc can be divided into 4 domains (from SE to NW): 1) the undeformed lonian abyssal plain, 2) the external evaporitic wedge, 3) the internal clastic wedge, 4) the Calabrian backstop (Variscan crystalline basement). The Calabrian accretionary wedge can also be divided laterally into two major lobes, the NE- and the SW lobes, and two minor lobes. The kinematics of the limit between the two major lobes is investigated and shown to be sinistral in the external (evaporitic) wedge. A network of radial slip lines within the southernmost external wedge unequivocally demonstrate ongoing dextral displacement of a rigid indenter (representing the corner of the clastic wedge) into the evaporitic wedge thereby confirming the geodynamic model of an active lateral slab tear fault here off eastern Sicily. The slab tear produces a series of major sub-parallel dextral strike-slip faults offshore Mt. Etna and south of
\end{abstract}


the Straits of Messina consistent with the relative motions between Calabria and the Peloritan domain (NE Sicily). Abundant strike-slip faulting, and wide-spread folding and thrusting observed throughout the entire accretionary wedge, indicate regional shortening between the lonian abyssal plain (foreland) and the Calabrian-Peloritan backstop caused by active subduction.

\section{Highlights}

Dextral strike-slip faulting occurs offshore E Sicily above a lateral slab tear fault. $\rightarrow$ Proposed dextral Ionian Fault becomes sinistral to the south, in external wedge. Compressional (folding and thrusting) tectonics occur throughout the wedge. Morpho-tectonics indicate ongoing subduction and advance of Calabrian backstop.

Keywords : subduction, active faults, Eurasia-Africa plate boundary, bathymetry, seismic profiles, accretionary wedge

\section{Introduction/Geodynamic setting}

The Ionian Sea in the Central Mediterranean straddles the Eurasia - Africa plate boundary and records a long history of sedimentation, erosion, vertical movements and tectonic activity. This region includes zones of strong instrumental and historic seismicity from western Greece to southern Italy (Fig. 1). The Calabrian arc, formed by the NW dipping Calabrian - Tyrrhenian subduction zone (Fig. 1 inset) is considered by many as the type example of a narrow, retreating slab (Faccenna et al., 2004; Rosenbaum et al., 2008). In contrast to the nearby Hellenic subduction zone, there are no known earthquakes with a shallow dipping thrust focal mechanism in the Calabrian fore-arc (Fig. 1). This observation has led several workers to question the activity of the subduction (Goes et al., 2004; Perouse et al., 2015) or some portion thereof (Neri et al., 2009; Polonia et al., 2011; 2016). 
1 Furthermore, the location and kinematics of the lateral slab tear faults often described as

2 "STEP" (subduction tear edge propagator) faults (Govers and Wortel, 2005) is controversial, 3 with many competing models proposed in recent years (Argnani and Bonazzi, 2005; Govers and Wortel, 2005; Polonia et al., 2011; 2016; Argnani et al., 2012; Orecchio et al., 2014; Gutscher et al., 2016; Barreca et al., 2016).

The geography and tectonics of the Italy region have been shaped by the evolution of a NW dipping subduction zone beneath SW Europe, since 35 Ma. Progressive SE-ward retreat of a slab of Tethys oceanic lithosphere initiated rifting and back-arc extension producing the Neogene basins of the western Mediterranean, e.g. the Gulf of Lion - Liguro-Provencal basin and the Tyrrhenian Sea (Malinverno and Ryan, 1986; Jolivet and Faccenna, 2000; Faccenna et al., 2001; 2004; 2014). Within the central and eastern Mediterranean today, there remain at most small fragments of the Tethyan oceanic domain, beneath the Ionian Sea abyssal plain and further east beneath the Herodotus abyssal plain (Faccenna et al., 2014). Tomographic data indicate only a narrow connection to the Wadati-Benioff zone beneath the SE Tyrrhenian Sea (Neri et al., 2009).

According to available geodetic data, there is slow, but significant convergence $(\geq 3$ $\mathrm{mm} / \mathrm{yr}$ ) occurring between the Hyblean platform (SE Sicily) and NE Sicily (the Peloritan Mountains domain) and slow (3-5 mm/yr) SE motion of the Calabrian block with respect to the Apulian and Hyblean domains (Serpelloni et al., 2010; D’Agostino et al., 2011; Devoti et al., 2011; Palano et al., 2012). These authors attribute most of this motion to the Calabria 21 subduction zone and to the SE-directed roll-back of the Calabria - Peloritan block. However, Sicily itself and the neighboring regions (Calabria, the Eolian islands, the Ustica compressional belt to the north and northwest, and the Pantellaria - Sicily Channel and Malta rifts to the south) appear to be composed of a mosaic of micro-blocks with slow moving and complex kinematics (Serpelloni et al., 2010; Palano et al., 2012; 2015; Barreca et al., 2016). 
The exact geometry and degree of activity of the fault network offshore Sicily in the

2 Ionian Sea remain uncertain, although the faults pose a significant seismic and tsunami hazard. Nearly 200,000 deaths have occurred in this region over the past 5 centuries (Jenny et al., 2006) and the sources of many of these earthquakes remain uncertain or disputed to this day (Piatanesi and Tinti, 1998; Gutscher et al., 2006; Aloisi et al., 2013). Since many of these earthquakes generated tsunamis, their source faults must be near the coast or offshore (Billi et al., 2010). Marine geophysical surveys combining seismic imaging and bathymetric swathmapping are the most effective methods used by earth scientists to identify tectonic processes (e.g. active faults) as well as sedimentary and diapiric, which shape the seafloor (Armijo et al., 2002; 2005; Loncke et al., 2006; Loubrieu et al., 2007; Graindorge et al., 2008;

Gutscher et al., 2009; Zitellini et al., 2009; Chiocci et al., 2011; Gutscher et al., 2016). high-resolution bathymetric data to test the predictions made by different tectonic models for the location and kinematics of the lateral slab edge fault systems, by examining certain key portions of the Calabrian accretionary wedge. A more general aim of this study is to characterize recent morpho-bathymetric features on the seafloor according to their origin (sedimentary, erosional, tectonic) with a special emphasis placed on the identification of active faults. To achieve this goal multi-beam bathymetric data will be supplemented by highresolution multi-channel seismic profiles.

2 Data

Several bathymetric surveys have acquired data since 2010 in the study area. Data from the following surveys are presented here: R/V Meteor cruise 86, 2010 PI - S. Krastel; MocoSed R/V PourquoiPas 2012 PI - T. Garlan; Circee R/V Suroît 2013 PI - M.-A. Gutscher; R/V Meteor cruise 111, 2014 PI's - H. Kopp, M.-A. Gutscher; R/V Meteor cruise 112, 2014 
1 PI - G. Bohrmann; Chianti R/V Sarmiento di Gamboa, 2015 PI's - C. Ranero, V. Sallares

2 (Fig. 2).

The new bathymetric compilation reveals the fine seafloor morphology of several

4 provinces in the Ionian Sea in unprecedented detail including: narrow, straight and sinuous

5 submarine canyons as well as broad flat-bottomed turbidite valleys, the $\geq 3 \mathrm{~km}$ high

6 bathymetric step formed by the Malta Escarpment, the Ionian Sea abyssal plain, the entire

7 extent of the Calabrian accretionary wedge and the westernmost portion of the Western

8 Mediterranean Ridge accretionary wedge, and finally, several mud volcanoes provinces on the

9 upper Calabrian accretionary wedge (Fig. 3). Six 2-D cross-sections crossing from the abyssal

10 domain to the Calabrian block are constructed and presented in order to define the various

11 structural domains composing the accretionary wedge and to observe their lateral variations 12 (Fig. 4).

Four multi-channel seismic profiles, crossing internal portions of the accretionary

14 wedge and the southern deformation front at its limit with the Ionian abyssal plain are

213 Results

presented here as well (Figure 5). These high-resolution seismic lines were acquired during the Circee marine geophysical survey, with the French research vessel Le Suroit in October 2013 using a $450 \mathrm{~m}$ long, 72-channel Sercel seismic streamer, with an average geophone spacing of $6.25 \mathrm{~m}$, towed $150 \mathrm{~m}$ behind the vessel. The seismic source was a 6 GI airgun array with a total volume of $111 \mathrm{cu}$ in fired at a cadence of once every $6 \mathrm{sec}$, for an average shot spacing of $16 \mathrm{~m}$ and a 24 fold coverage for each Common Mid Point.

\subsection{Morpho-structural domains of the Calabrian arc}

As can be seen in map view (Figs. 2, 3) and in the relief cross-sections (Fig. 4) the Ionian Sea - Calabrian subduction complex can be divided into 4 general structural domains from SE to NW: 1) the Ionian abyssal plain, 2) the external (evaporitic) wedge, 3) the internal 
1 (clastic) wedge and finally 4) the Calabrian slope and the rugged land topography of the

2 Calabrian block itself. This four-part division has already been pointed out in previous studies

3 (Minelli and Faccenna 2010; Polonia et al., 2011; Gallais et al., 2012) and is easily observed

4 at regional scale (Fig. 3). Further subdivision based on purely morphological criteria is

5 possible and several sub-domains within the clastic (internal) accretionary wedge are

6 identified here (Fig. 3). These Calabrian arc domains are bounded to the west by the Malta-

7 Hyblean Escarpment (MHE), to the south by the Medina Seamounts, to the NE by the

8 Apulian Escarpment and to the east by the Western Mediterranean Ridge accretionary

9 complex (Fig. 4). Here with the benefit of high-resolution seismic lines and bathymetric data

10 we can observe the transition between these domains and fine scale variations within the

11 domains themselves.

$12 \quad 3.2$ Seismic Profiles

13 The deepest domain is the Ionian abyssal plain (water depth $\sim 4000 \mathrm{~m}$ ), which includes

14 fields of sediments waves located at the foot of the Medina Seamounts seen in bathymetry

15 (Fig. 2) and also imaged in seismic profiles (Fig. 5a). These sub-parallel linear ridges are

16 oriented $\mathrm{N} 120-\mathrm{N} 150^{\circ} \mathrm{E}$, at a $1-2 \mathrm{~km}$ wavelength and typically $20-30 \mathrm{~m}$ in height (Fig. 2).

17 The northern and eastern Ionian abyssal plain ends at the deformation front of the Calabrian

18 and West Mediterranean Ridge accretionary complexes, respectively (Fig. 2). The two

19 deformation fronts have several $\mathrm{N} 30-\mathrm{N} 40^{\circ} \mathrm{E}$ oriented embayments (Fig 2 - limit between the

20 violet and blue), which are also parallel to spurs of the Medina seamounts and appear to

21 reflect variations in the geometry of the Ionian Sea basement (Gallais et al., 2011).

The external (evaporitic) portion of the Calabrian wedge begins with a very shallow

23 frontal slope $\left(0.5^{\circ}\right)$ (Fig. 4). In seismic profiles (Fig. 5) one can observe that this is the result

24 of gradual thickening of the incoming sedimentary section through gentle anticlinal folds and

25 thrusts above a regional detachment within the Messinian evaporites (Fig. 5a,c), as discussed 
1 in many earlier studies (Finetti, 1982; Cernobori et al., 1996; Minelli and Faccenna 2010;

2 Polonia et al., 2011; Gallais et al., 2012). The frontal-most anticlines have a typical spacing of

3 about $2 \mathrm{~km}$ and as one moves upslope into the accretionary wedge, the spacing diminishes to

4 about $1 \mathrm{~km}$ and then reaches roughly $0.5 \mathrm{~km}$ (Fig. 5a). This is due to stretching, shearing and

5 rotation of the thrust slices, as is commonly observed in analog modeling experiments for a

6 low basal friction (Gutscher et al., 1996; 1998). In the three western cross-sections this external evaporitic wedge forms a modest bathymetric bulge with a convex crest (Fig. 4a - 4c) behind which is a slightly deeper, flat-lying area containing numerous medium to large basins ( $\geq 20 \mathrm{~km}$ in size), (lower basins in Fig. 3). This latter area typically marks the boundary zone to the internal clastic wedge. Seismic profile CIR-10 (Fig. 5a) shows a transition from tightly spaced, and sheared thrust slices to a zone of roughly $2-\mathrm{km}$ wide bumps separated by narrow intervening basins. In the map view of the bathymetry (Fig. 2) these narrow, elongate and enclosed basins have the appearance of furrows or gashes. One possible explanation for their origin could be local dissolution of the Messinian evaporites on the flank of syncline anticline pairs, where they may come into direct contact with seawater. The next seismic profile upslope on the SW lobe CIR-02 (Fig. 5b) shows the typical thrust spacing within the internal (clastic) accretionary wedge to be about $2-5 \mathrm{~km}$. This is substantially more than in the external wedge and indicates a deeper decollement level in the clastic wedge as has been partly imaged in deeper penetration seismic reflection profiles (Polonia et al., 2011; Gallais et al., 2012). The NW end of seismic profile CIR-02 shows a 21 rather steep, faulted slope with evidence for mixed fault kinematics (thrusts and normal faults) and probably marks the transition to the generally more rugged upper slope (Fig. 3).

The longest seismic profile CIR-16 presents a complete cross-section through the three deepest structural domains and crosses the limit between the SW lobe and the NE lobe as well (Fig. 5c). The external wedge with abundant gentle anticlinal folds is rather similar to 
1 the geometry further west (Fig. 5a), with an average thrust spacing of $2 \mathrm{~km}$, diminishing to

2 less than $1 \mathrm{~km}$ within $20 \mathrm{~km}$ of the deformation front. It is interesting to note that the surface

3 deformation front (visible in the bathymetric map Fig. 2) does not coincide with the deeper

4 deformation front, which extends out another $15 \mathrm{~km}$ below the abyssal plain where very

5 gentle undulations in the Messinian evaporites are observed (Fig. 5c). At a distance of $35-70$

$6 \mathrm{~km} \mathrm{NW}$ of the deformation front, the zone of narrow enclosed basins is reached. Here the

7 band of strong reflectivity, thought to mark the top of the Messinian, appears to just reach the

8 base of the deepest troughs/gashes, which could allow evaporite dissolution to occur. Further

9 to the NW there is a somewhat bumpy plateau and then 2 - 3 deep clefts, one of which

10 represents the limit between the SW and the NE lobe. Continuing to the NW, there are once

11 again tightly spaced anticlinal folds reminiscent of the zone close to the deformation front, a

12 somewhat steeper slope, culminating in a structural high (at profile $\mathrm{km} 50-60$ ) with some

13 thrust faults visible beneath. Then further NW there is a fairly broad depressed area (profile

$14 \mathrm{~km} 25-50$ ) dominated by ridges and intervening troughs (Fig. 5C). The stratigraphy in the

15

16 small syn-tectonic basins suggests mixed fault kinematics with alternating thrust and normal throws. These apparently contradictory observations are most easily explained by strike-slip faulting, producing alternating transtensional and transpressional deformation. The uppermost portion of the profile $(0-20 \mathrm{~km})$ images a mud volcano province, dominated by Pythagoras mud volcano (with its two adjacent moats), well described in earlier studies (Praeg et al., 2009; Ceramicola et al., 2014). Two additional (previously unreported) mud volcanoes (Odysseus, Circee) are also imaged. The entire province is underlain by thrust faults seen in the seismic profile (Fig. 5c) and consistent with the interpretation of mud volcanism related to compressional tectonics (Praeg et al., 2009).

\section{Discussion}


1 There is disagreement regarding the current kinematics of the Calabrian wedge and the

2 surface expression of the lateral slab tear fault (or STEP) with three primary competing

3 models (Argnani and Bonazzi, 2005; Gutscher et al., 2016; Polonia et al., 2011; 2016) (Fig.

4 6). Each kinematic model also makes contrasting predictions as to which portions of the

5 Calabrian wedge should currently exhibit compressional deformation (Fig. 6 red lineaments).

6 In order to test these predictions we will examine in detail four key sub-regions, identify the

7 major faults and the kinematics, and seek evidence of compressional deformation.

\subsection{S Calabria / NE Sicily offshore Mt. Etna}

This region includes the Straits of Messina and two steep continental slopes, the NE Sicily margin and the Southernmost Calabria margin (Fig. 7a). The former can be divided into two segments the NE-SW trending Peloritan margin (north of Mt. Etna) and the northernmost portion of the NNW-SSE trending MHE, which terminates just SE of Mt. Etna near Catania. The Peloritan and S Calabrian submarine slopes are incised by numerous, parallel linear canyons, oriented orthogonally to the coastline. The northernmost MHE, though also steep is less strongly incised. The abundant parallel canyons may be due to connection of very steep and often dry riverbeds onshore ("fiumare", subject to torrential seasonal flash floods, Fig. 7a) to the submarine canyons offshore, with recent incision caused by flash floods. This probably also reflects the recent rapid uplift of the S Calabrian and Peloritan domains (Westaway 1993), while the area south of Catania (the Catania coastal plain in the foreland of the Gela Nappe) may be slowly subsiding.

The deeper offshore is dominated by three NW-SE oriented gently curving to tightly sinuous canyons and by 3-4 NW-SE oriented lineaments on the seafloor with lengths of several tens of kilometers (Fig. 7a). The latter are marked by elongate pressure ridges (popups) transpressional/transtensional jogs and the southernmost was interpreted to be an active dextral strike-slip fault (Gutscher et al., 2016). The northernmost of these has been named the 
1 Ionian Fault (dashed blue line Fig. 7a) (Polonia et al., 2016) and appears to merge into the

2 Messina canyon and may thus be partially masked. Kinematically this structure has been

3 proposed to be a major dextral strike-slip fault, accommodating the differential motion

4 between the S Calabrian basement and the Peloritan block, and linked to the ongoing NW-SE

5 extension in the Straits of Messina (Palano et al., 2012; 2015; Polonia et al., 2016) (Fig. 6).

6 The bathymetric data from the continental slope SE of Catania show distinct slope breaks

7 parallel to the coastline. This is consistent with a reactivation of the northern MHE by 2 - 3

8 normal faults, in agreement with observations from multi-channel seismic profiles (Argnani

9 and Bonazzi, 2005; Argnani et al., 2009; Gutscher et al., 2016).

$10 \quad 4.2$ The vortex

11 This region covers a large portion of the limit between the NE and SW lobes of the accretionary wedge (Fig. 7b), where the Ionian Fault is proposed to traverse (Polonia et al., 2016) (Fig. 6c). It also includes a 0.5 - $1.0 \mathrm{~km}$ high scarp, we name "the Wall" (Fig. 7b) oriented ENE-WSW, with several similarly oriented linear ridges to the north and south. These appear to be anticlinal thrust ridges. The south-western portion features two large flat basins with several isolated ridges oriented almost randomly and a few sub-parallel ridges oriented E-W at the SW extremity. The most striking features in this sub-region are a series of curved lineaments on either side of the proposed Ionian Fault, which resemble a vortex, with left-handed curvature (center and lower right of Fig. 7b). Several jagged, enclosed basins are also observed here, with the same general curvature. These curved lineaments indicate 21 regional counter-clockwise rotation, which would require sinistral shear along the proposed Ionian fault. The intersection of the proposed Ionian fault and "the Wall" shows no dextral offset of the scarp, which would be expected if the Ionian fault exhibited dextral shear along 24 its entire length. However, the slight S-shaped trend of the "the Wall" is consistent with modest $(5-10 \mathrm{~km})$ sinistral displacement along the proposed Ionian fault trace. 


\subsection{Oblique ridges and troughs domain}

This sub-region represents the core of a large kidney shaped zone, which forms an internal arc within the NE lobe (Figures 2, 3 and Fig. 8a). This depression, with curved subparallel ridges and troughs, has been identified by previous bathymetric mapping (ChamotRooke et al., 2005; Loubrieu and Mascle, 2007; Praeg et al., 2009) and is the site of numerous documented mud volcanoes as well (Praeg et al., 2009; Ceramicola et al., 2014). Some authors interpreted the NE-SW oriented elongate troughs as evidence of widespread normal faulting thought to be expressions of gravitational spreading and collapse (Chamot-Rooke et al., 2005; Rabaute and Chamot-Rooke, 2014). With the newly available high-resolution bathymetry, however, the morphology can now be seen to be a series of criss-crossing ridges and troughs, oriented primarily $\mathrm{N} 20^{\circ} \mathrm{E}$ to $\mathrm{N} 30^{\circ} \mathrm{E}$ and $\mathrm{N} 60^{\circ} \mathrm{E}$ to $\mathrm{N} 70^{\circ} \mathrm{E}$ and intersecting obliquely (Fig. 8a). Together with the seismic profile CIR-16, which shows alternating thrust and normal throws on faults within a $30 \mathrm{~km}$ distance (Fig. 5d), this argues strongly in favor of widespread strike-slip deformation, which can produce transpressional ridges and elongate troughs (Fig. 8a).

\subsection{Slip line domain}

The southern portion of the SW lobe shows the progressive evolution of the gentle folds at the deformation front (dashed yellow and green lines at the SE and SW corners) towards tighter folds further north (Fig. 8b). Northwards of $36^{\circ} \mathrm{N}$ elongate depressions are observed and become one of the most prominent morphological features. These depressions resembling furrows or gashes are sub-parallel to the deformation front and numerous small parallel ridges are still widespread. However, the most striking feature in this sub-region is the extraordinary set of lineaments appearing to radiate outwards from the NW corner of the region, and more specifically from the southern extremity of an elongate basin. This basin is described in an earlier study as a transtensional basin related to the South Alfeo fault, 
1 interpreted to represent the lateral slab edge tear fault at the limit between the clastic wedge

2 (to the east) and the evaporitic wedge (to the west) (Gutscher et al., 2016). These lineaments

3 extend on average $30-60 \mathrm{~km}$ into the external (evaporitic) wedge. Such radially oriented

4 lineaments, known as slip-lines are common in the foreland of rigid indenters and have been

5 observed previously in analog modeling studies (Tapponier et al., 1982; Dominguez et al.,

6 2000) and in nature in front of seamounts subducting beneath the Costa Rica margin

7 (Dominguez et al., 1998). The NW-SE oriented slip-lines cross-cut the generally E-W

8 oriented anticlinal folds formed in the Plio-Quaternary cover above the Messinian salt. This

9 indicates that deformation post-dates the Plio-Quaternary and is currently active.

105 Summary

We present a detailed structural interpretation of the Calabrian wedge (Fig. 9). The

12 Calabrian wedge can be divided laterally into 2 major lobes and 2 minor lobes: a small

13 trapped lobe (W and NW of Alfeo Seamount), the large SW lobe, the large NE lobe, and a

14 smaller far eastern lobe near the Apulian Escarpment, (although this last region is not well

15 resolved by the bathymetric data) (Figs. 3, 9). The boundary between the external (evaporitic

16 wedge) and internal (clastic wedge) is locally expressed by a change in the seafloor

17 morphology. The outermost portion of the evaporitic wedge is characterized by abundant

18 short wavelength $(1-2 \mathrm{~km})$ low amplitude $(100-200 \mathrm{~m})$ anticlines. In the external

19 (evaporitic) wedge compressional, salt-cored thrust anticlines are abundant at the deformation

20 front and in the lower most slope. Toward the mid- and upper slope and along the crest of the

21 external wedge, the morphology is dominated by narrow, elongate enclosed basins

22 (furrows/gashes). The internal (clastic wedge) exhibits a very wide range of seafloor

23 morphology (Fig. 3). Anticlinal folds when present have much longer wavelengths than in the

24 external wedge. An internal arc within the eastern part of the clastic wedge is dominated by 
1 oblique ridges and elongate parallel troughs. In the upper part of the internal wedge (NE lobe)

2 numerous mud volcanoes are present (Figs. 8a, 9).

The counterclockwise rotation in the vortex indicates sinistral shear along the limit

4 between the NE and SW lobes (Figs. 7b, 9). This is further suported by the trend of the 1-km

5 high escarpment (the "Wall"). These observations contradict the kinematic interpretation of

6 the Ionian Fault as being a major dextral strike-slip fault along the entire boundary between

7 the two lobes (Fig. 6c) as has been suggested in earlier work (Polonia et al., 2011; 2016).

8 Major strike slip faults are observed in the uppermost portion of the wedge south of the Straits

9 of Messina, with dextral kinematics indicated either by structural markers (Gutscher et al.,

10 2016) or by regional GPS observations (Palano et al., 2012; 2015). Dextral strike-slip

11 kinematics in the E Sicily offshore region is also supported by available focal mechanisms

12 here (Presti et al., 2013; Musumeci et al., 2014) (Fig. 1). The northwestern portion of the

13 Ionian Fault, though not clearly expressed in the morphobathymetry is likely dextral as well

14 (Fig. 9) as suggested by the few available focal mechanisms here (Presti et al., 2013; Polonia

et al., 2016) (Fig. 1). The dextral strike-slip kinematics of the northernmost Ionian Fault does

16 not extend along the limit between the two lobes. Instead, we interpret that this dextral

17 movement connects into the region of oblique ridges and troughs and into the out-of sequence

18 thrusts of the internal arc (Figs. 8a, 9). Active deformation of the SW lobe is expressed, by

19 gentle folding of the uppermost turbidite sedimentation at the deformation front as seen in the

20 bathymetry (Fig. 8b) and seismic profiles (Figs. 5a, 5c) and by the superimposed slip-lines

21 indicating expulsion of the SW lobe in response to the SE advance of a rigid indenter (Figs.

$228 b, 9)$. This supports the kinematic model of a dextral strike-slip limit at the boundary

23 between the external (evaporitic) and internal (clastic) wedge (Fig. 6b) for this portion of the

24 wedge (Gutscher et al., 2016). This contradicts the prediction of the alternate model that the

25 SW lobe has been abandoned (Fig. 6c) because the Peloritan backstop has become 
1 kinematically inactive (Polonia et al., 2016). GPS observations (d'Agostino et al., 2011;

2 Palano et al., 2012; 2015) indicate more rapid SE motion of the Calabrian block, with

3 associated extension expressed by normal faulting in the straits of Messina and Calabria

4 (Presti et al., 2013) (Fig. 1) and consistent with the mechanism of the 1908 Messina

5 earthquake (Aloisi et al., 2013). However, the morpho-tectonics of the westernmost

6 accretionary wedge and the active set of radiating slip lines clearly indicate ongoing dextral

7 strike slip movement here (Fig. 6b). While it is difficult to determine the current slip rate

8 along the tectonically active $\mathrm{W}$ boundary of the Calabrian wedge, a rough estimate can be

9 obtained by considering the shape of the external evaporitic wedge and assuming the limit

10 between the internal and external wedge was initially parallel to the Calabrian block (oriented

11 roughly NE-SW). In this case, the more rigid internal clastic wedge has advanced at least 110

$12 \mathrm{~km}$ to the SE since the Messinian times (about $5.5 \mathrm{Ma}$ ). This would represent a minimum

13 "long-term" estimate of $2 \mathrm{~mm} / \mathrm{yr}$. The uncertainty of this value is quite high, since the total

14 displacement could in fact be much larger, possibly as high as $300-400 \mathrm{~km}$ (considering that

the majority of the Tyrrhenian Sea backarc basin opened during this period (Facenna et al., 2001; 2004; Gutscher et al., 2016). And of course, kinematics may have changed significantly since the Messinian, with the most rapid movements occurring during the opening of the Vavilov and Marsili basins (Faccenna et al., 2001) and much slower rates of motion at present. An exact value could best be obtained by the deployment of long-term observational equipment on the seafloor across this boundary.

\section{Conclusions}

The high-resolution morpho-bathymetric map of the Ionian Sea seafloor images active sedimentary and tectonic processes on the seafloor in unprecedented detail. Deep incision and erosion of steep slopes (Malta Escarpment, Calabrian offshore), linear and sinuous canyons, and fields of sediment waves are the primary sedimentary features observed. The tectonics 
1 and internal mechanics of the Calabrian accretionary wedge vary strongly from one structural

2 domain to the next. Compressional (thrust and folding) tectonics are the primary mode of

3 deformation in the external wedge. Near the E Sicily margin / Straits of Messina area, dextral

4 strike-slip faulting is the dominant mode of deformation. Throughout the internal wedge there

5 is an interplay of compressional and strike-slip deformation, especially within the internal arc

6 of the NE lobe. Kinematic indicators exclude large-scale dextral shear in the central and SE

7 portions of the proposed Ionian Fault. A field of radiating slip-lines in the external wedge

8 (SW lobe), cross-cutting Plio-Quaternary thrust anticlines indicates a SE-moving indenter

9 consistent with large scale dextral shear along the Alfeo fault system and suggests this is the

10 currently active lateral slab tear.

7 Acknowledgments:

We thank the officers and crews of the R/V Le Suroit, the R/V PourquoiPas2, the R/V

14 Meteor, and the R/V Sarmiento di Gamboa, whose excellent work was crucial to acquire the 15 data presented here. We acknowledge INSU for funding related to the CIRCEE cruise and the 16 European Union $7^{\text {th }}$ Framework project ASTARTE on Tsunami Hazard in Europe for support 17 to MAG. The data published in the paper will contribute to the next EMODnet bathymetry database that will be a multi-resolution DTM with a common resolution of 3 arc seconds. This will be published at the portal in the Bathymetry Viewing and Downloading service from where users can download tiles from this layer in a range of formats. In addition, higher resolution DTMs will be produced as hotspots and for the near coastal areas and coastal zones, where possible. Emodnet website: http://www.emodnet-bathymetry.eu/ 
1 Aloisi, M., Bruno, V., Cannavo, F., Ferranti, L., Mattia, M., Monaco, C., and Palano, M., 2013, Are the source models of the M7.1 1908 Messina earthquake reliable? Insights from a novel inversion and sensitivity analysis of leveling data: Geophys. J. Int. 192, 1025-1041, doi:10.1093/gji/ggs062.

Argnani, A., 2009. Evolution of the southern Tyrrhenian slab tear and active tectonics along the western edge of the Tyrrhenian subducted slab. In: Van Hinsbergen, D. J. J., Edwards, M. A. and Govers, R (Eds.): Collision and Collapse at the Africa-ArabiaEurasia Subduction Zone. Geological Society London, Special Publications, 311, 193212. DOI: $10.1144 / \mathrm{SP} 311.7$

Argnani, A., and Bonazzi, C., 2005, Malta Escarpment fault zone offshore eastern Sicily: Plio-Quaternary tectonic evolution based on new multi-channel seismic data: Tectonics 24, TC4009, doi:10.1029/2004TC001656.

Argnani, A., Armigliato, A., Pagnoni, G., Zaniboni, F., Tinti, S. and Bonazzi, C., 2012, Active tectonics along the submarine slope of south-eastern Sicily and the source of the 11 January 1693 earthquake and tsunami. Nat. Hazards Earth Syst. Sci. 12, 1311-1319. doi:10.5194/nhess-12-1311-2012

Armijo, R., B. Meyer, S. Navarro, G. King, and A. Barka, 2002, Asymmetric slip partitioning in the Sea of Marmara pull-apart: A clue to propagation processes of the North Anatolian Fault, Terra Nova 14, p. 80-86.

Armijo, R., Pondard, N., Meyer, B., Ucarkus, G., Mercier de Lepinay, B., Malavieille, J., Dominguez, S., Gutscher, M.-A., Schmidt, S., Beck, C., Cagatay, N., Cakir, Z., Imren, C., Eris, K., Natalin, B., Özalaybey, S., Tolum, L., Lefevre, I., Seeber, L., Gasperini, L., Rangin, C., Emre, O., and Sarikavac, A., 2005. Submarine fault scarps in the Marmara Sea pull-apart (North Anatolian Fault): Implications for seismic hazard in Istanbul. Geochemistry Geophysics Geosystems 6, Q06009, doi:10.1029/2004GC000896. 
1 Barreca, G., Scarfi, L., Cannavo, F., Koulakov, I., and Monaco, C., 2016. New structural and seismological evidence and interpretation of a lithospheric scale shear-zone at the southern edge of the Ionian subduction system (central-eastern Sicily, Italy). Tectonics 35, doi:10.1002/2015TC004057.

Billi A., Minelli, L., Orecchio, B., and Presti, D., 2010. Constraints to the cause of three historical tsunamis $(1908,1783$, and 1693) in the Messina Straits region, Sicily, Southern Italy. Seismol. Res. Letters 81, 907-913, doi:10.1785/gssrl.81.6.907.

Ceramicola, S., Praeg, D., Cova, A., Accettella, D., and Zecchin, M., 2014. Seafloor distribution and last glacial to post-glacial activity of mud volcanoes on the Calabrian accretionary prism, Ionian Sea. Geo-Marine Letters 26, 1849-1865. doi: 10.1007/s00367013-0354-y.

Cernobori, L., Hirn, A., McBride, J.H., Nicolich, R., Petronio, L., Romanelli, M. and STREAMERS/PROFILES Working Groups, 1996, Crustal image of the Ionian basin and its Calabrian margins: Tectonophysics 264, 175-189.

Chamot-Rooke, N., Rangin, C., Le Pichon, X., Dotmed Working Group, 2005. DOTMEDDeep Offshore Tectonics of the Mediterranean: a synthesis of deep marine data in eastern Mediterranean. Mémoire de la Société géologique de France \& American Association of Petroleum Geologists . special number, 177: 64 pp, 9 maps with CD-ROM.

Chiocci, F.L., Coltelli, M., Bosman, A., and Cavallaro, D., 2011. Continental margin largescale instability controlling the flank sliding of Etna volcano: Earth and Planetary Science Letters $305,57-64$.

D'Agostino, N., D'Anastasio, E., Gersavi, A., Guerra, I., Nedimović, M.R., Seeber, L., and Steckler, M.S., 2011. Forearc extension and slow rollback of the Calabrian Arc from GPS measurements. Geophysical Research Letters, 38, L17304, doi:10.1029/2011GL048270. 
1 Dominguez, S., Lallemand, S.E., Malavieille, J., von Huene, R., 1998. Upper plate 2 deformation associated with seamount subduction. Tectonophysics 293 (3-4), 207-224.

3 Dominguez, S., Malavieille, J., Lallemand, S.E., 2000. Deformation of accretionary wedges in response to seamount subduction: insights from sandbox experiments. Tectonics 19 (1), 182-196.

Faccenna, C., Funiciello, F., Giardini, D. and Lucente, F.P., 2001. Episodic back-arc extension during restricted mantle convection in the Central Mediterranean. Earth and Planetary Science Letters 187, 105-116.

Faccenna, C., Piromallo, C., Crespo-Blanc, A., Jolivet, L., and Rossetti, F., 2004, Lateral slab deformation and the origin of the western Mediterranean arcs: Tectonics 23, TC1012, doi:10.1029/2002TC001488.

Faccenna, C., Becker, T.W., Auer, L., Billi, A., Boschi, L., Brun, J.-P., Capitanio, F.A., Funiciello, F., Horvath, F., Jolivet, L., Piromallo, C., Royden, L., Rossetti, F., Serpelloni, E., 2014. Mantle dynamics in the Mediterranean, Rev. Geophys. 52, 283-332, doi:10.1002/2013RG000444.

Gallais, F., Gutscher, M.-A., Graindorge, D., Chamot-Rooke, N., and Klaeschen, D., 2011. A Miocene tectonic inversion in the Ionian Sea (Central Mediterranean): evidence from multi-channel seismic data. JGR, v. 116, B12108, doi:10.1029/2011JB008505.

Gallais, F., Gutscher, M.A., Graindorge, D., and Klaeschen, D., 2012. Two-stage growth of the Calabrian accretionary wedge in the Ionian Sea (Central Mediterranean): Constraints from depth migrated multi-channel seismic data: Marine Geology 326-328, 28-45.

Gallais, F., Graindorge, D., Gutscher, M.-A., and Klaeschen, D., 2013, Propagation of a lithospheric tear fault (STEP) through the western boundary of the Calabrian accretionary wedge offshore eastern Sicily (southern Italy): Tectonophysics 602, 141-152 doi:10.1016/j.tecto.2012.12.026 
1 Goes, S., Giardini, D., Jenny, S., Hollenstein, C., Kahle, H.-G., and Geiger, A., 2004. A recent reorganization in the south-central Mediterranean. Earth and Planetary Science Letters, 226, 335-345, doi :10.1016/j.eps1.2004.07.038

Govers, R., and Wortel, M.J.R., 2005. Lithosphere tearing at STEP faults: Reponse to edges of subduction zones. Earth and Planetary Science Letters 236, 505-523.

Graindorge, D., Klingelhoefer, F., Sibuet, J.-C., McNeill, L., Henstock, T., Dean, S., Gutscher, M.-A., Dessa, J.-X., Permana, H., Singh, S., Leau, H., White, N., Carton, H., Malod, J.-A., Rangin, C., Aryawan, G., Kumar-Chaubey, A., Chauhan, A., Galih, D., Greenroyd, C.J., Laesanpura, A., Prihantono, J., Royle, G., and Shankar, U., 2008. Impact of lower plate structure on upper plate deformation at the NW Sumatran convergent margin from seafloor morphology. Earth Planet. Sci. Letters 275, 201-210.

Gutscher, M.-A., Kukowski, N., Malavieille, J., and Lallemand, S., 1998. Material transfer in accretionary wedges from analysis of a systematic series of analog experiments. Journal of Structural Geology 20, 407-416.

Gutscher, M.-A., Roger, J., Baptista, M.A., Miranda, J.M., and Tinti, S., 2006. The source of the 1693 Catania earthquake and tsunami (Southern Italy): New evidence from tsunami modeling of a locked subduction fault plane. Geophysical Research Letters 33, 8, L08309 10.1029/2005GL025442.

Gutscher, M.-A., Dominguez, S., Westbrook, G.K., Gente, P., Babonneau, N., Mulder, T., Gonthier, E., Bartolome, R., Luis, J, Rosas, F., Terrinha, P., and the Delila and DelSis Scientific Teams, 2009. Tectonic shortening and gravitational spreading in the Gulf of Cadiz accretionary wedge: observations from multi-beam bathymetry and seismic profiling. Sp. Vol. on Submarine instabilities, Marine and Petroleum Geology 26, 647659, doi:10.1016/j.marpetgeo. 2007.11.008. 
1 Gutscher, M.-A., Dominguez, S., Mercier de Lepinay, B., Pinheiro, L., Gallais, F.,

2 Babonneau, N., Cattaneo, A., LeFaou, Y., Barreca, G., Micallef, A., and Rovere, M., 3 2016. Tectonic expression of an active slab tear from high-resolution seismic and bathymetric data offshore Sicily (Ionian Sea). Tectonics 35, 1, doi:10.1002/2015TC003898.

6 Jenny, S., Goes, S., Giardini, D., and Kahle, H.-G., 2006. Seismic potential of Southern Italy: Tectonophysics 415, 81-101 doi:10.1016/j.tecto.2005.12.003.

Jolivet, L. and Faccenna, C., 2000. Mediterranean extension and the Africa-Eurasia collision. Tectonics 19(6): 1095-1106.

Loncke, L., Gaullier, V., Mascle, J., Vendeville, B., and Camera, L., 2006. The Nile deep-sea fan: An example of interacting sedimentation salt tectonics, and inherited subsalt paleotopographic features. Marine and Petroleum Geology 23, 297-315,

Malinverno, A., and W.B. Ryan, 1986. Extension in the Tyrrhenian Sea and shortening in the Appenines as a result of arc migration driven by sinking of the lithosphere. Tectonics, 5, $227-245$.

Minelli, L., and Faccenna, C., 2010. Evolution of the Calabrian accretionary wedge (central Mediterranean). Tectonics 29, TC4004.

21 Musumeci, C., Scarfî, L., Palano, M., and Patanè, D., 2014. Foreland segmentation along an active convergent margin: new constraints in southeastern Sicily (Italy) from seismic and geodetic observations. Tectonophysics 630, 137-149, doi:10.1016/j.tecto.2014.05.017. 
1 Neri, G., B. Orecchio, C. Totaro, G. Falcone, and D. Presti, 2009. Subduction beneath southern Italy close the ending: Results from seismic tomography, Seismol. Res. Lett., $80,63-70$.

Orecchio, B., Presti, D., Totaro, C. and Neri, G., 2014. What earthquakes say concerning residual subduction and STEP dynamics in the Calabrian Arc region, south Italy. Geophys. J. Int., 199, 1929-1942.

Palano, M., Ferranti, L., Monaco, C., Mattia, M., Aloisi, G., Bruno, V., Cannavò, F., and Siligato, G., 2012, GPS velocity and strain fields in Sicily and southern Calabria, Italy: Updated geodetic constraints on tectonic block interaction in the central Mediterranean: Journal of Geophysical Research 117, B07401, doi:10.1029/2012JB009254.

Palano, M., Schiavone, D., Loddo, M., Neri, M., Presti, D., Quarto, R., Totaro, C., and Neri, G., 2015. Active upper crust deformation pattern along the southern edge of the Tyrrhenian subduction zone (NE Sicily): Insights from a multidisciplinary approach. Tectonophysics 657, B07401, doi:10.1016/j.tecto.2015.07.005.

Pérouse, E., Chamot-Rooke, N., Rabaute, A., Briole, P., Jouanne, F., Georgiev, I., Dimitrov, D., 2012. Bridging onshore and offshore present-day kinematics of central and eastern Mediterranean: Implications for crustal dynamics and mantle flow. Geochem. Geophys. Geosyst., Vol. 13(9), doi:10.1029/2012GC004289.

Piatanesi, A., and Tinti, S., 1998, A revision of the 1693 eastern Sicily earthquake and tsunami, J. Geophys. Res. 103, 2749-2758.

Polonia, A., Torelli, L., Mussoni, P., Gasperini, L., Artoni, A., and Klaeschen, D., 2011, The Calabrian arc subduction complex in the Ionian Sea: regional architecture, active deformation and seismic hazard: Tectonics 30, TC5018, doi:10.1029/2010TC002821.

Polonia, A., Torelli, L., Artoni, A., Carlini, M., Faccenna, C., Ferranti, L., Gasperini, L., Klaeschen, D., Monaco, C., Neri, G., Nijholt, N., Orecchio, B., Wortel, R., Govers, R., 
2016. The Ionian and Alfeo-Etna fault zones: New segments of an evolving plate boundary in the central Mediterranean Sea? Tectonophysics 675, 69-90, doi:10.1016/j.tecto.2016.03.016.

Praeg, D., Ceramicola, S., Barbieri, R., Unnithan, V., Wardell, N., 2009. Tectonically-driven mud volcanism since the late Pliocene on the Calabrian accretionary prism Central Mediterranean Sea. Marine and Petroleum Geology 26, 1849-1865.

Presti, D., Billi, A., Orecchio, B., Totaro, C., Faccenna, C., Neri, G., 2013. Earthquake focal mechanisms, seismogenic stress, and seismotectonics of the Calabrian Arc, Italy. Tectonophysics 602, 153-175, doi:10.1016/j.tecto.2013.01.030.

Rabaute, A., and Chamot-Rooke, N., 2014. Active tectonics of the Africa-Eurasia Boundary from Algiers to Calabria, Map at 1: 500000 scale, Paris, ISBN 978-2-9548197-0-9.

Rosenbaum, G., Massimo, G., Lucente, F.P., Peccerillo, A., and Miller, M.S., 2008. Kinematics of slab tear faults during subduction segmentation and implications for Italian magmatism. Tectonics 27, TC2008, doi:10.1029/2007TC002143.

Serpelloni, E., Bürgmann, R., Anzidei, M., Baldi, P., Mastrolembo Ventura, B. and Boschi, E., 2010. Strain accumulation across the Messina Straits and kinematics of Sicily and Calabria from GPS data and dislocation modeling. Earth Planet. Sci. Lett. 298(3-4), 347360, doi:10.1016/j.eps1.2010.08.005.

Tapponnier, P., Peltzer, G., Le Dain, A.-Y., Armijo, R., Cobbold, P., 1982. Propagating extrusion tectonics in Asia: new insights from simple experiments with plasticine. Geology 10 (12), 611-616.

Westaway, R., 1993. Quaternary uplift of southern Italy. Journal of Geophysical Research 98, B12, 21, 741-21, 772 .

Zitellini, N., Gracia, E., Matias, L., Terrinha, P., Abreu, M.A., DeAlteriis, G., Henriet, J.P., Danobeitia, JJ., Masson, D., Mulder, T., Ramella, R., Somoza, L., and Diez, S., 2009. 

Sci. Lett. 280, p. 13-50, doi :10.1016/j.epsl.2008.12.005.

3

4 
29 Appendix - characteristics of the seismic data acquisition system

3 A marine geophysical survey was conducted onboard the French research vessel Le Suroit in 4 October 2013 using high-resolution seismic reflection profiling and bathymetric 5 swathmapping. The seismic data were acquired using a $450 \mathrm{~m}$ long, 72-channel Sercel 6 seismic streamer with an average geophone spacing of $6.25 \mathrm{~m}$ and towed $150 \mathrm{~m}$ behind the 7 vessel. The seismic source was a 6 GI airgun array with a total volume of $111 \mathrm{in}^{3}$ fired at a 8 cadence of once every $6 \mathrm{sec}$, for an average shot spacing of $16 \mathrm{~m}$ and a 24 -fold coverage for 9 each Common Mid Point. 
1 Figure Captions:

2

3 Figure 1: General location map of southern Italy region, showing; seismicity (colored circles)

4 from PDE-NEIC catalog (1973-2016), and CMT thrust faulting focal mechanisms (in black)

5 for the period 1976-2008. Yellow circles are historical earthquakes, with estimated magnitude

$6 \geq 7$. Shown in red are typical focal mechanisms for crustal seismicity in Calabria and Eastern

7 Sicily sub-regions, taken from recent publications (Presti et al., 2013; Musumeci et al., 2014;

8 Barreca et al., 2016; Polonia et al., 2016). Black thrust teeth show limits of the Calabrian and

9 Western Mediterranean Ridge accretionary wedges. Inset: Seismicity cross-section obtained

10 by projecting the hypocenters within the yellow brackets onto the yellow line.

12 Figure 2: Color shaded hill relief of new bathymetric compilation and topography (60 m grid) with an artificial illumination from the north. Inset map shows the geographic coverage of the different data sets used in the compilation. The resolution of each bathymetric survey as well as the terrestrial data is provided in the legend. (Please note the straight bands in the abyssal 16 plain (magenta color) and adjacent polygons are artifacts due to the swaths of the echosounder 17 - see also Supplemental Figure 5.)

Figure 3: Morpho-structural domains of the study area overlain on a gray shaded hill relief map. Also shown are the location of the bathymetric-topographic cross-sections (Fig. 4)

21 (magenta brackets and thin dashed lines) and the seismic profiles presented below (Figure 5)

22 (green lines). AS = Alfeo Seamount.

24 Figure 4: Bathymetric-topographic cross-sections $(\mathrm{VE}=10)$ (for positions see Figure 3). 
1 Figure 5: Seismic reflection profile (high-resolution 72-channel data) $(\mathrm{VE}=6)$

2 A: line CIR-10 crossing the SW deformation front (SW lobe)

3 B: line CIR-02 crossing thrust anticlines in the internal (clastic) wedge of the SW lobe

4 C: line CIR-16 crossing the S deformation front, the boundary between the two lobes, and

5 ending at the Pythagoras mud volcano province

6 D: line CIR-18 crossing thrust anticlines in the internal (clastic) wedge of the E lobe

8 Figure 6: Three hypotheses for the current kinematics of the Calabria subduction and its SW

9 lateral slab edge tear fault (or "STEP" fault) with the major active fault labeled in red (general layout of the figure modified after Gutscher et al., 2016). Magenta regions are the Variscan 11 basement of the Peloritan (NE corner of Sicily labeled Pelor.) and Calabria, which have migrated to the SE in response to slab roll-back, with this movement indicated schematically by the thick red arrows. Red faults (thick lines) and red lineaments (fine lines) are interpreted to be active, green lineaments are considered to be inactive, while brown lineaments (in the internal wedge) are thought to be less active. Thrust teeth at the deformation front are filled (black) if considered active or unfilled if considered inactive. The internal (clastic) portion of the Calabrian accretionary wedge is shown in white and the external (evaporitic) portion of the accretionary wedge is shown in yellow. A - The tear fault coincides with the MaltaHyblean escarpment, expressed primarily by normal faulting, though some strike-slip is also possible (Argnani and Bonazzi, 2005; Govers and Wortel, 2005; Argnani et al., 2012). B -

21 The tear fault follows the dextral, transtensional South and North Alfeo fault sytems 22 (Gutscher et al., 2016), rooting below Mt. Etna (Gvirtzman and Nur, 1999). C - The tear fault is interpreted to be the dextral Ionian fault, which forms the boundary between the SW and

24 NE lobes of the Calabrian accretionary wedge (Polonia et al., 2011; 2016). 
1 Figure 7: Detailed morpho-tectonic maps indicating submarine canyons and channels (shown

2 as thin black lines), major tectonic lineaments as medium black lines and major faults as thick

3 black lines (dashed where uncertain or inferred) with symbols for sense of motion. The

4 proposed Ionian fault is shown as a dashed blue line. Inferred and/or known mud volcanoes

5 shown in light red shading. Flat and enclosed basins shown in light yellow shading.

6 A: The S Calabria - NE Sicily - Mt. Etna region, with the Straits of Messina, submarine 7 canyons and major strike-slip faults.

8 B: The "vortex" region, showing the location of a $1 \mathrm{~km}$ high thrust-fault scarp labelled "the

9 Wall". The curvature of the vortex indicates counterclockwise rotation, requiring sinistral 10 shear along the boundary between the lobes.

12 Figure 8: Detailed morpho-tectonic maps (same symbols as Figure 7).

A: Upper internal accretionary wedge with numerous oblique ridges and large elongate troughs (shaded yellow) and also spanning the mud volcano provinces of Pythagoras mud volcano and Madonna del Ionio mud volcano. Note the SE boundary of the Calabrian backstop (thick black line with thrust teeth)

B: Morpho structural analysis of the SW lobe of the accretionary wedge, with gentle thrust anticlines (in the south) and a series of slip-lines, radiating from the $\mathrm{S}$ corner of the clastic wedge, indicating the presence of a rigid, dextral indenter moving to the SE.

21 Figure 9: Tectonic map drawn on the basis of structural analysis of the bathymetric 22 compilation (Fig. 2) and existing publications. Thrust faults (thick lines, with black teeth); al., 2006; Palano et al., 2012) 


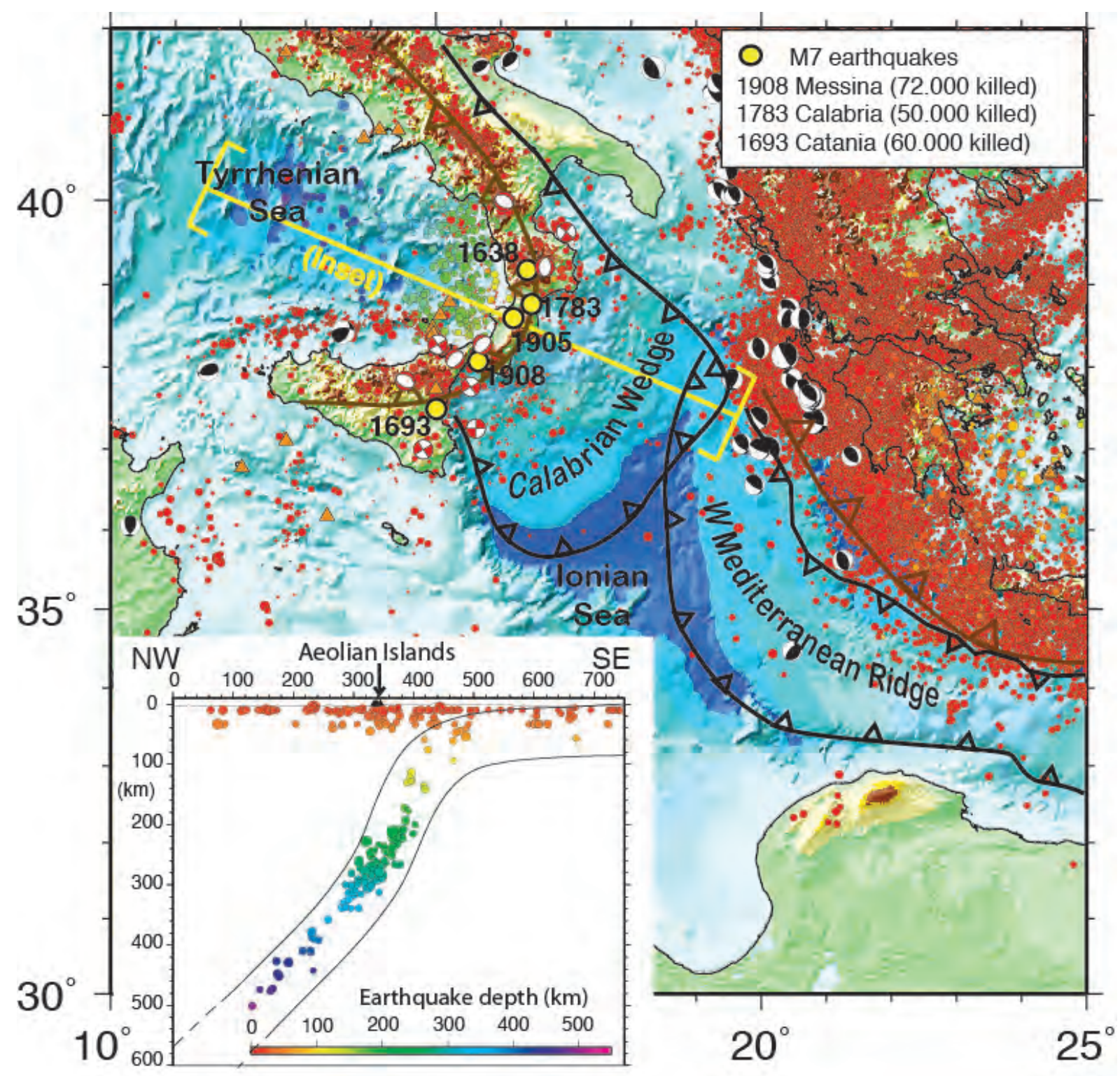

Fig. 1 


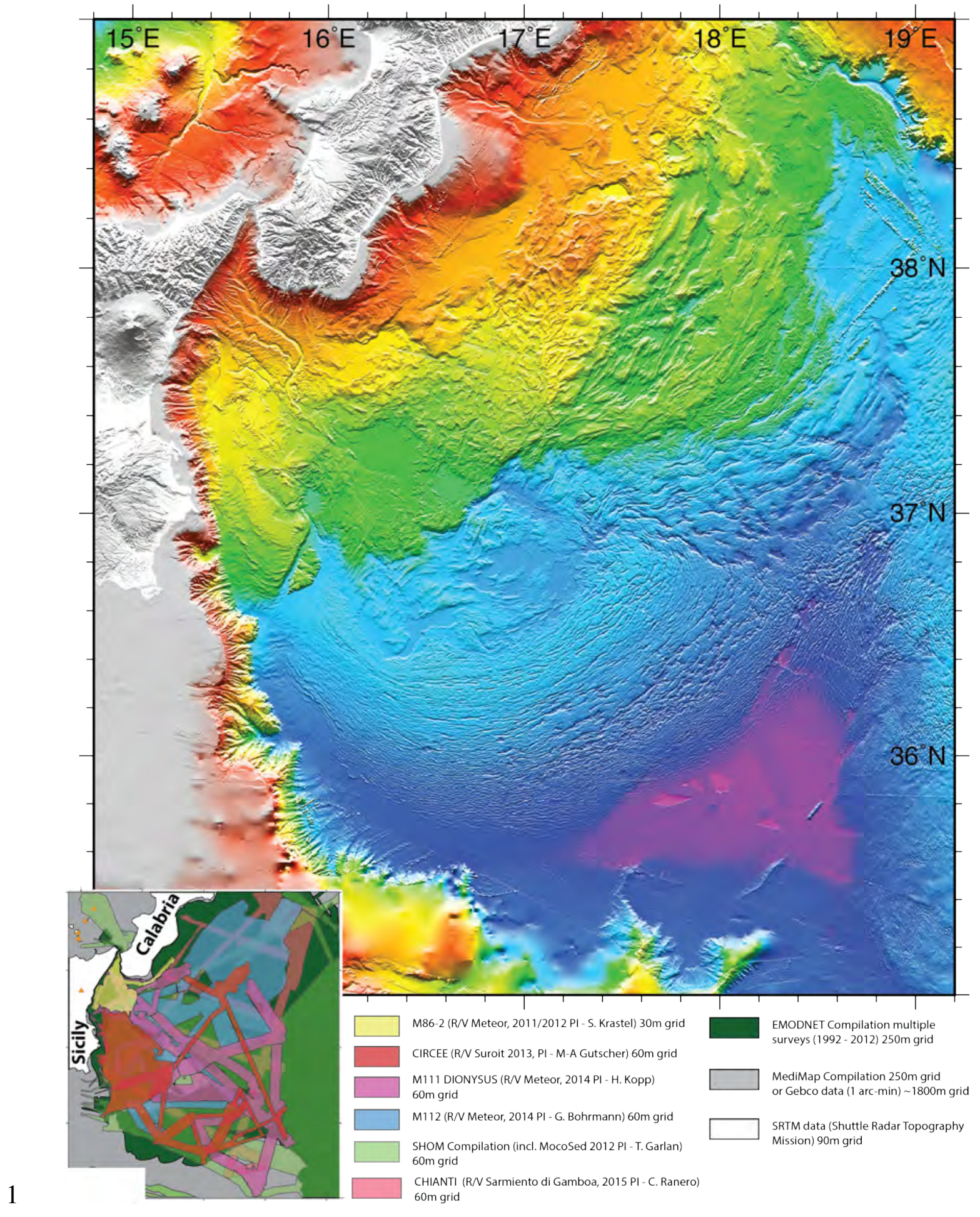

Fig. 2 


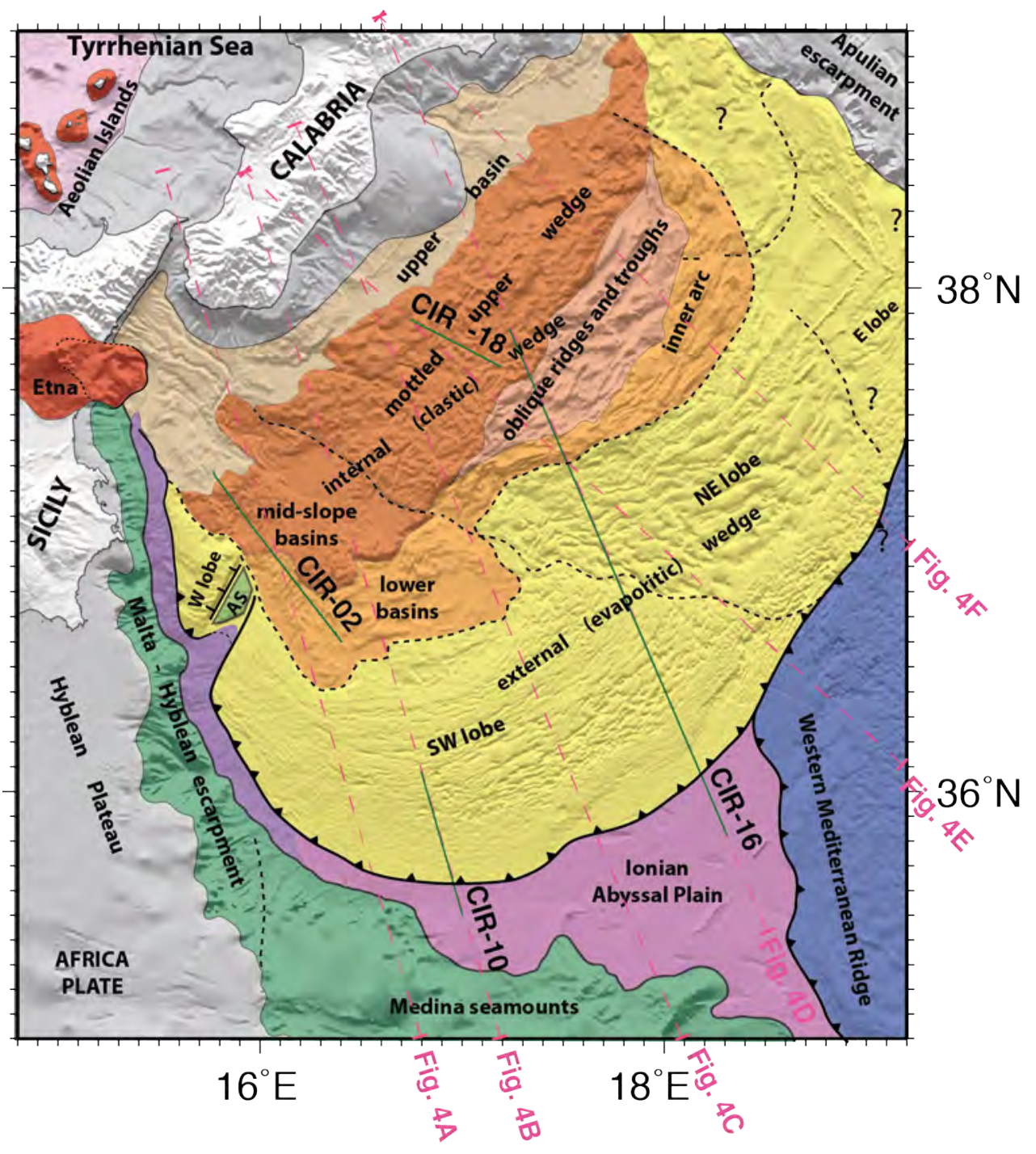

$2 \quad$ Fig. 3 
NW

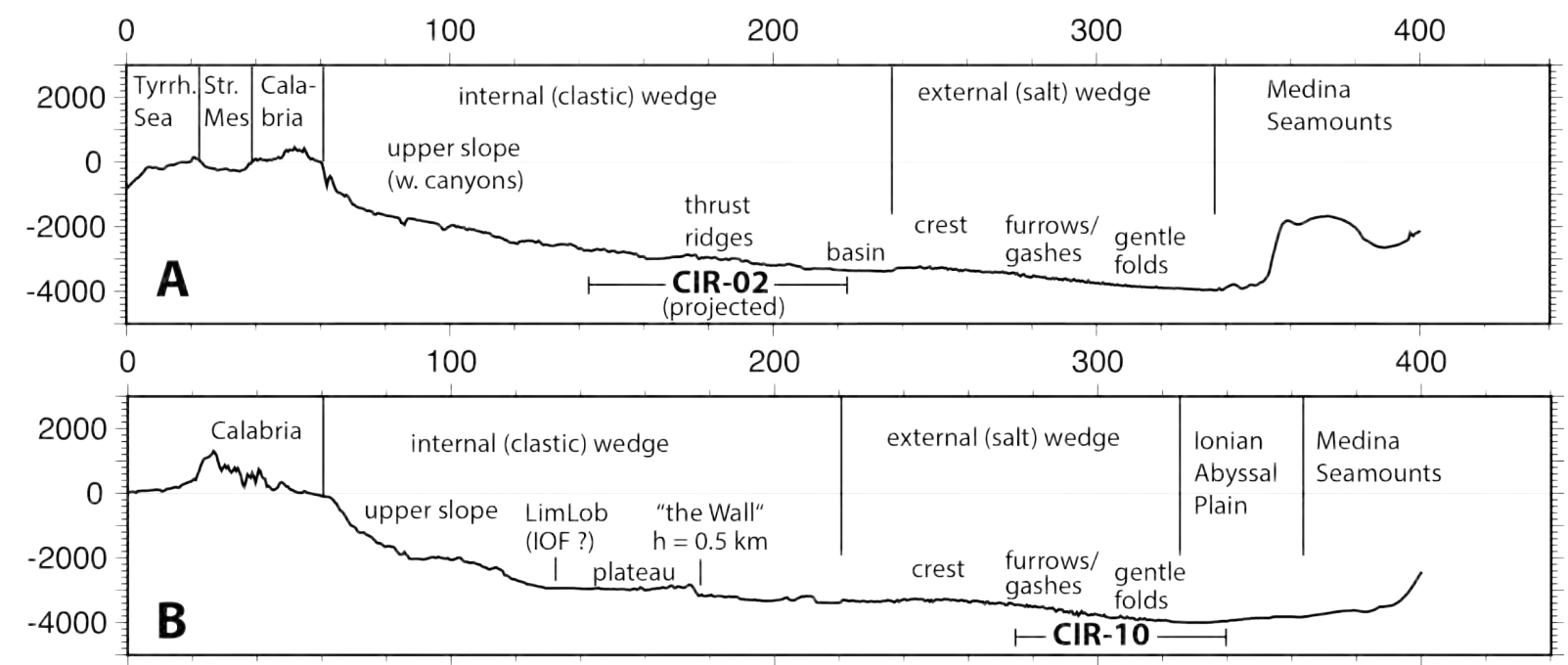
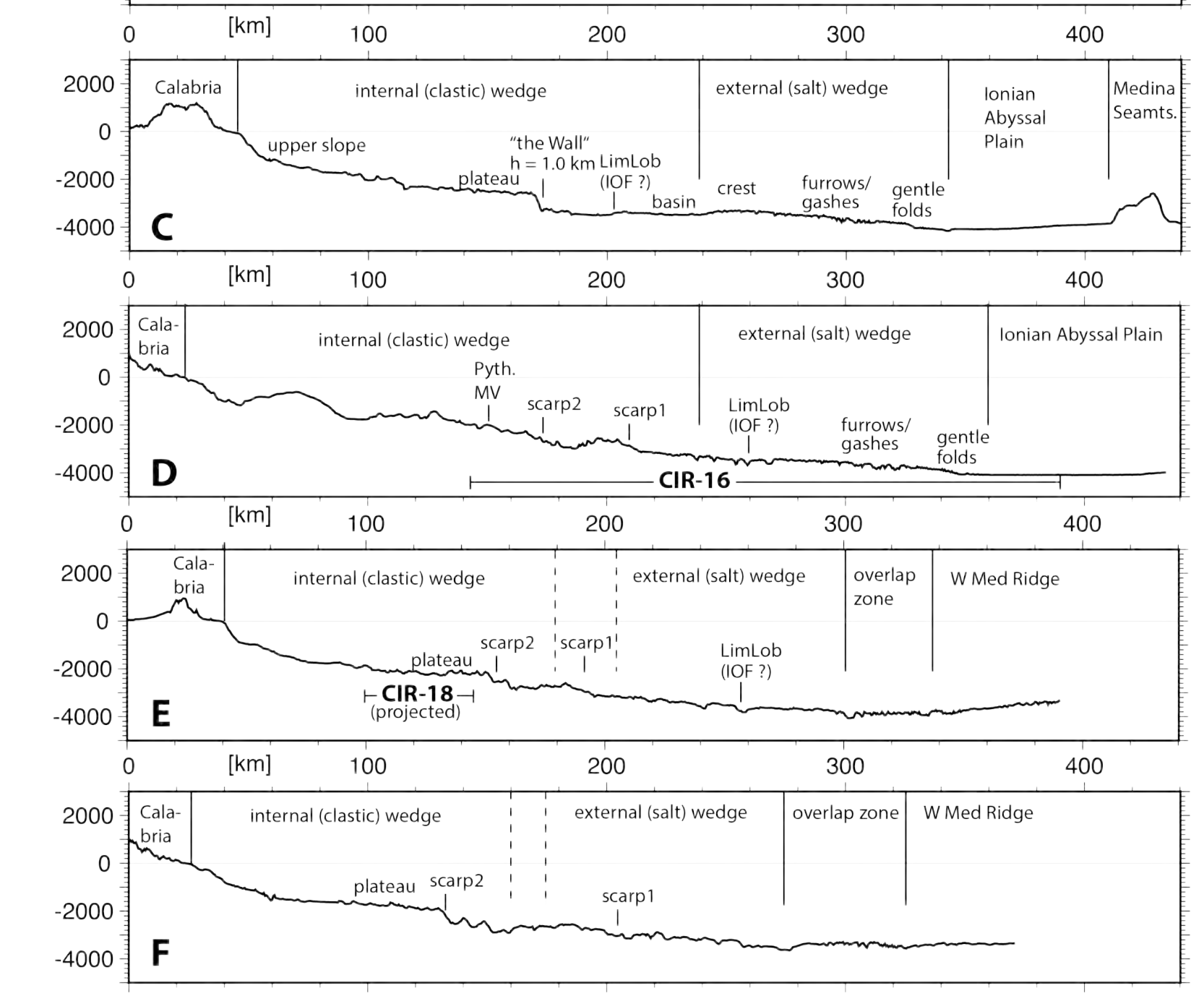

2 Fig. 4 
A $\mathrm{NN}$

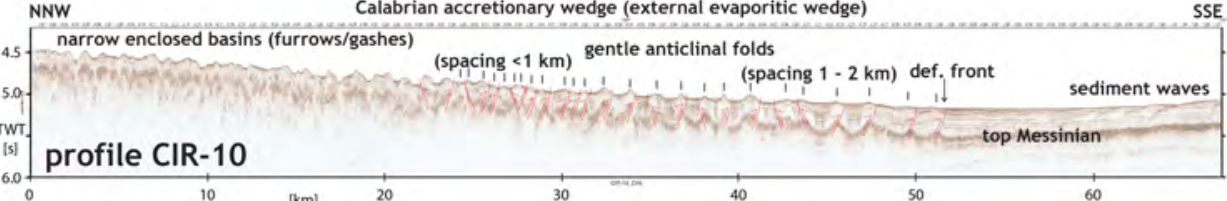

D NW

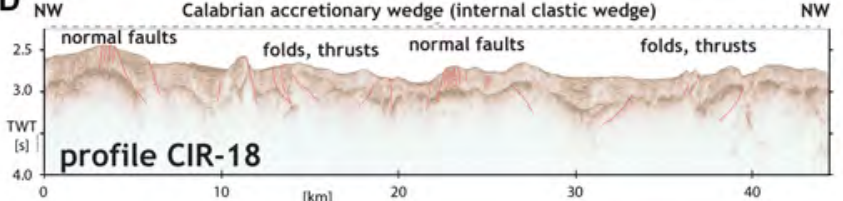

B

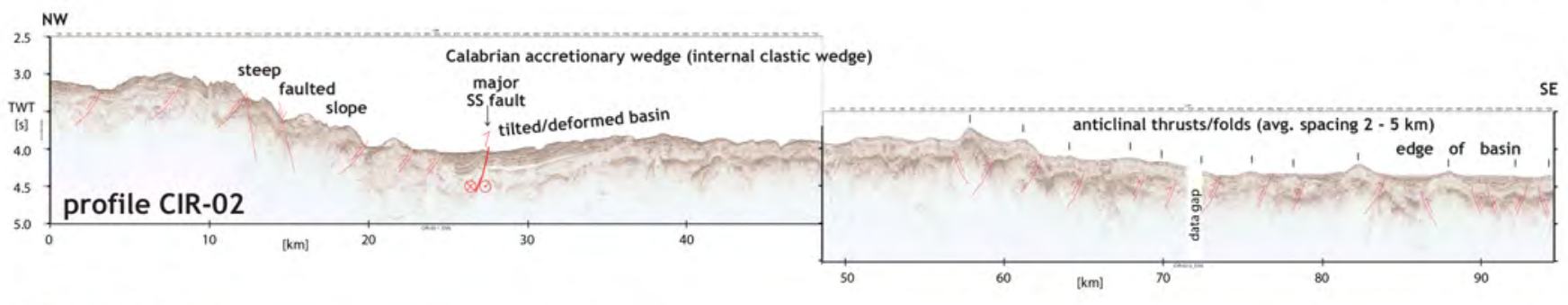

C

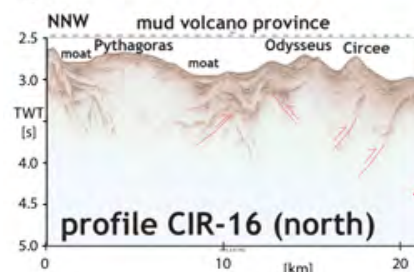

Calabrian accretionary wedge (internal clastic wedge)

tightly spaced anticlinal folds (spacing $<1 \mathrm{~km}$ )
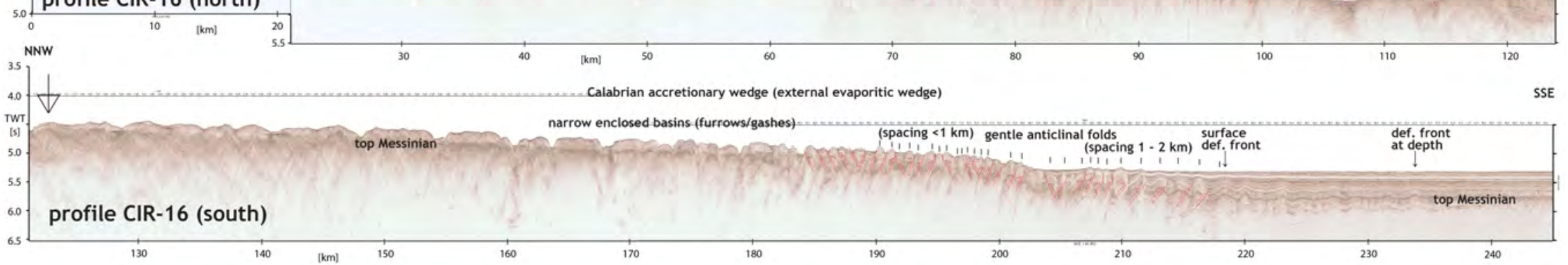


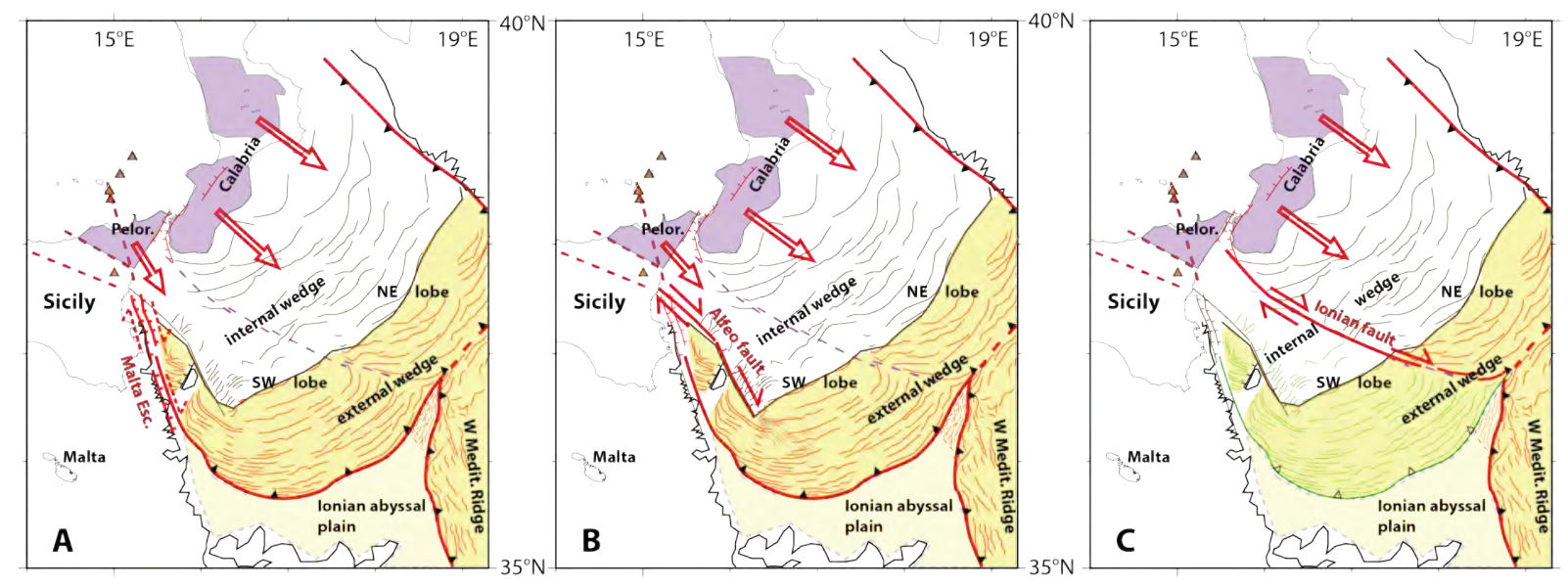

2 Fig. 6

3 

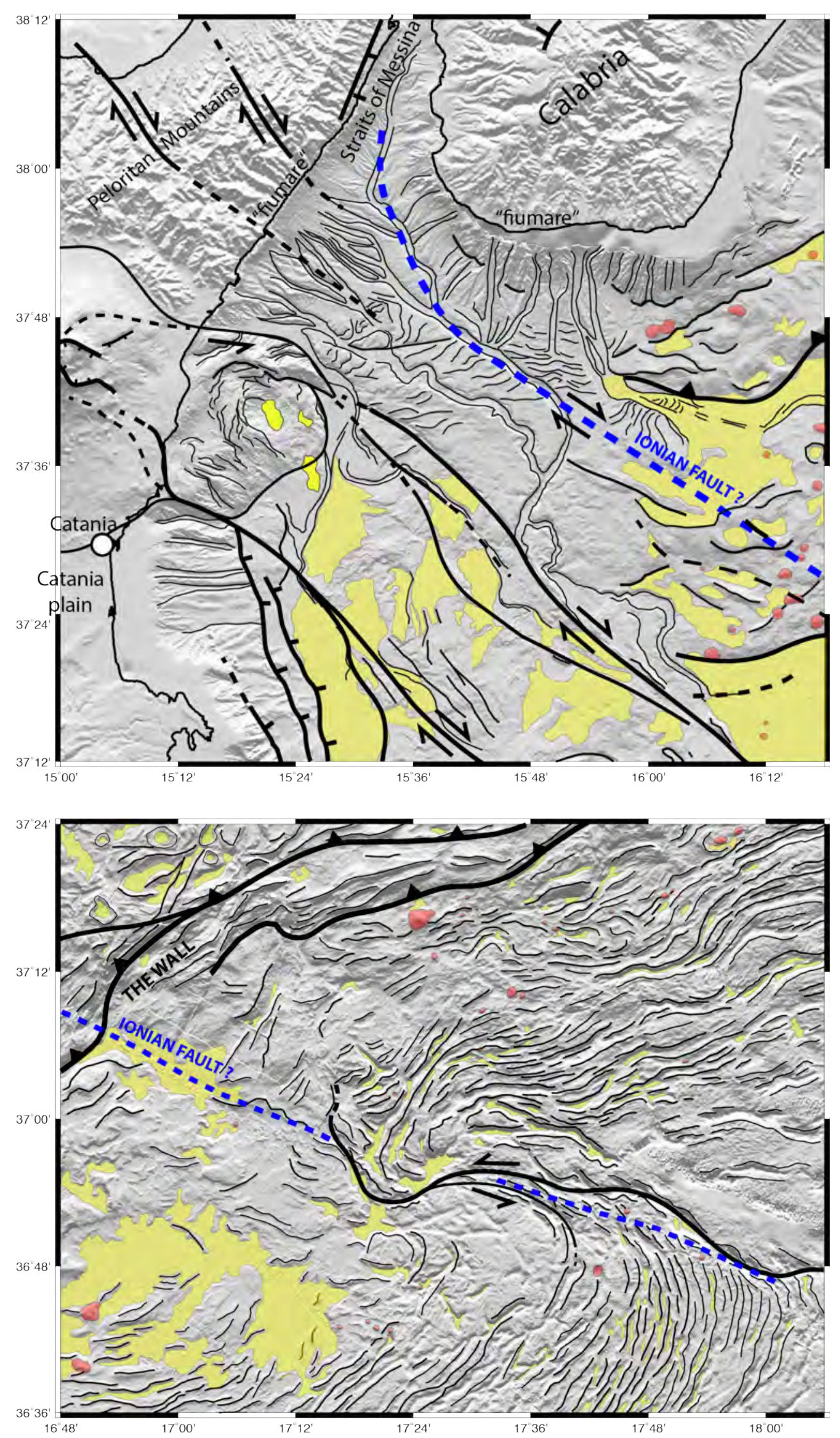

$3 \quad$ Fig. 7 


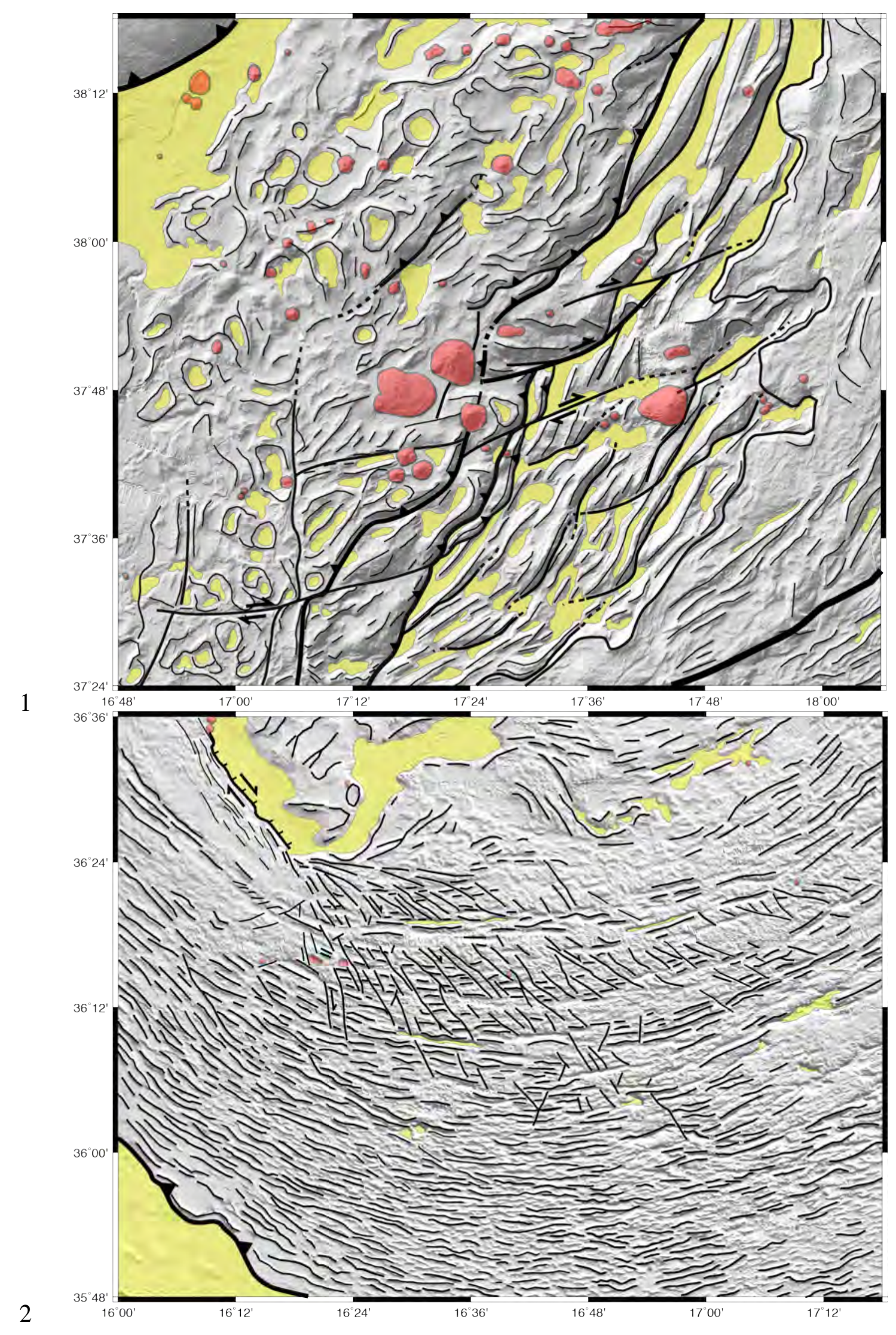

Fig. 8 


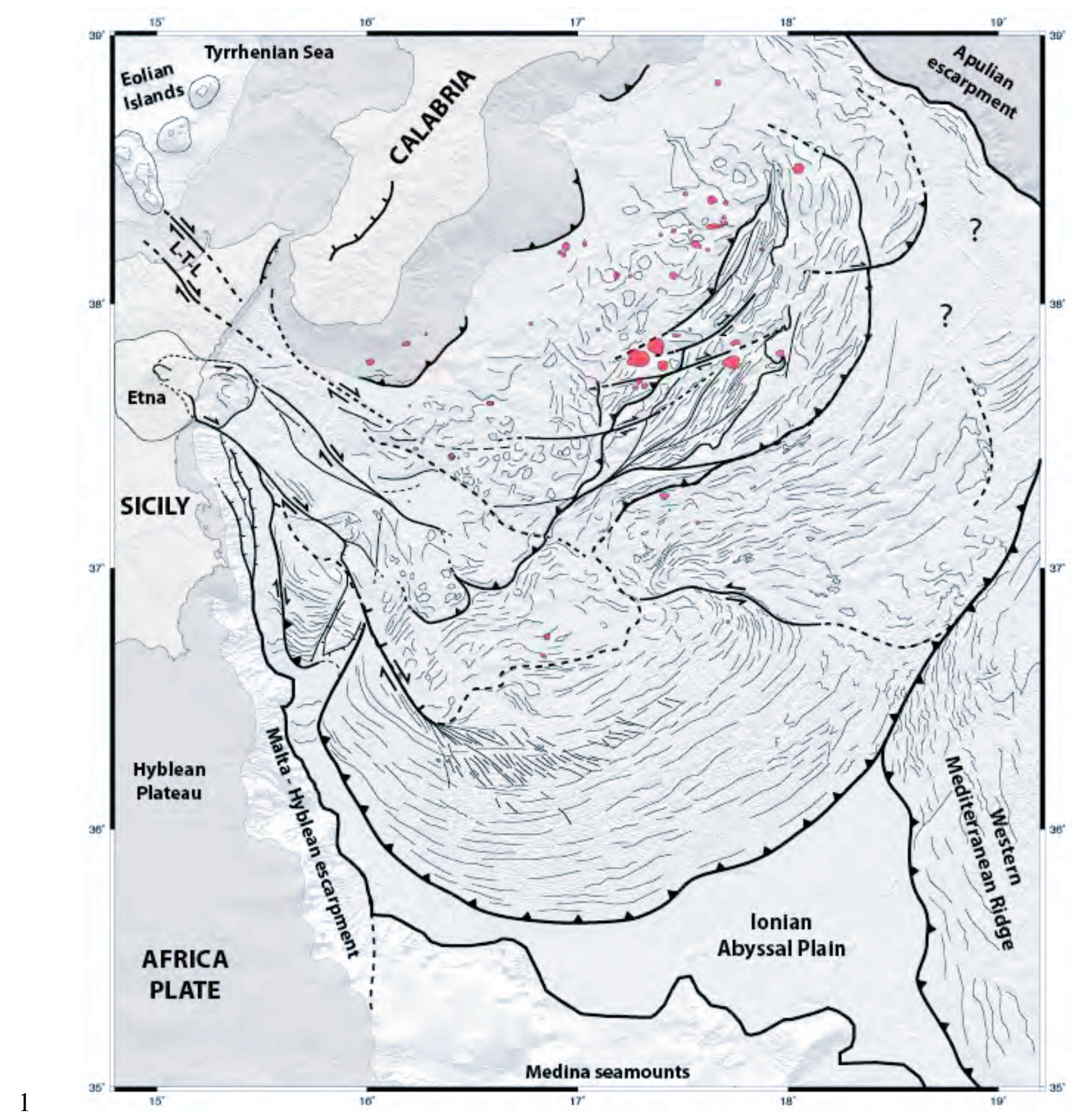

2 Fig. 9 